DOI 10.37882/2223-2974.2020.11.23

\title{
ПРАВОВАЯ ПРИРОДА ЦИФРОВЫХ ПРАВ КАК ГРАЖДАНСКО-ПРАВОВОЙ КАТЕГОРИИ
}

\section{LEGAL NATURE OF DIGITAL RIGHTS AS A CIVIL LEGAL CATEGORY}

\section{T. Mayboroda}

Summary: The article examines the prerequisites for the legislative regulation of digital rights as a civil legal category that arose during the development of the information and telecommunications network "Internet», and the legal nature of this phenomenon, which is of a complex systemic and structural nature. Based on the analysis of the essence of digital rights as a legal phenomenon, the prospects for development and legislative consolidation are identified.

Keywords: digital rights, tokens, cryptocurrency, information and telecommunication network, civil law, prerequisites for the emergence.
$\mathrm{B}$ настоящее время в России насчитывается 109,6 млн интернет-пользователей, а уровень проникновения информационно-телекоммуникационной сети «Интернет» достигает 76\% (при этом 85\% лиц используют сеть «Интернет» ежедневно, а 11\% - не реже, чем раз в неделю) [1].

Несмотря на отсутствие юридически закрепленного понятия сети «Интернет» в законодательстве Российской Федерации, под которым понимается «всемирная система объединенных компьютерных сетей, построенная на базе протокола IP и маршрутизации IP-пакетов, посредством которой распространяется информация различных форматов» [2], в связи с активным использованием информационных продуктов и технологий в сети «Интернет» появилась необходимость в их правовой регламентации. Данное обстоятельство обусловило принятие Федерального закона от 18 марта 2019 года № 34-Ф3 «О внесении изменений в части первую, вторую и статью 1124 части третьей Гражданского кодекса Российской Федерации», который закрепил «цифровые права» как новую гражданско-правовую категорию в отечественном законодательстве.

Одним из свойств сети «Интернет», как информационного пространства, является коммуникационность, то есть возможность взаимодействия субъектов. Такое информационное взаимодействие всегда будет опосредованно системой, благодаря которой оно происходит. На наш взгляд, именно это свойство сети «Интернет» в наибольшей степени повлияло на создание

\author{
Майборода Татьяна Юрьевна \\ К.ю.н., Курганский государственный университет \\ xxx092020@gmail.com
}

Аннотация: В статье рассматриваются предпосылки законодательной регламентации цифровых прав как гражданско-правовой категории возникшей, в ходе развития информационно-телекоммуникационной сети «Интернет», и правовая природа данного явления, носящая комплексный системно-структурный характер. На базе анализа сущности цифровых прав как правового явления выявлены его перспективы развития и законодательного закрепления.

Ключевые слова: цифровые права, токены, криптовалюта, информационнотелекоммуникационная сеть, гражданское право, предпосылки возникновения.

цифровых прав.

Однако, чтобы определить юридическую природу и, следовательно, перспективы законодательной регламентации цифровых прав необходимо обратиться предпосылкам их появления.

Говоря о создании цифровых прав («токенов»), важнейшую роль играет технология «блокчейн», которую с юридической точки зрения можно рассматривать как «децентрализованную распределенную базу данных («учетную книгу») всех подтвержденных транзакций, совершенных в отношении определенного актива, в основе функционирования которой лежат криптографические алгоритмы» [3].

В технологическом обзоре, представленном Национальным институтом стандартов и технологий США (NIST), «блокчейн» определяется как «распределенные цифровые реестры криптографически подписанных транзакций, сгруппированных в блоки» [4]. Технология «блокчейн» стала основой для создания платежной системы одноранговой сети - «биткоин».

Появление новой платежной системы, которая не регулируется существующим законодательством (т.К. деньги в этой системе не выступают платежными единицами) и при этом является анонимной, транснациональной и не имеет единого центра управления, вызвало серьезные опасения со стороны государств. Например, в России законодательно до сих пор не решена судьба крип- 
товалют, в то время как в Японии криптовалюта получила статус платежного средства, а в США считается активом, с доходов от которого необходимо уплачивать налог.

Помимо привычного использования «блокчейн»технологий в области финансов, эта технология так же позволяет решать иные задачи, такие как управление данными, подтверждение прав доступа, в том числе подтверждение авторских прав, заключение «смартконтрактов», поскольку «блокчейн», не только хранит данные о транзакциях криптовалюты, но обеспечивает хранение и обработку информации при сохранении конфиденциальности и информационной безопасности размещенных в систему персональных данных.

В связи с началом активного использования технологии «блокчейн» (конец 2000-х - начало 2010-х гг. XXI века), и в частности продуктов, создаваемых на ее основе, таких как «криптовалюта» и «токен», появилась необходимость в правовом регулировании деятельности, осуществляемой с помощью данной технологии, в том числе придание правового статуса «токенам»и «криптовалютам». Определение их правовой природы позволяет регулятору либо подвести их под известный правовой режим, либо дает основания для определения нового правового режима [5].

В практическом срезе термин «токен» часто используется как обозначение валюты (монет) в цифровой среде. Так, например, новым вариантом привлечения внешних инвестиций стало ICO (Initial Coin Offering) - первичное размещение токенов, с целью продажи цифровых токенов за криптовалюты или фиатные деньги среди инвесторов [6].

В этой связи представляется справедливым суждение М. Свона, о том, что «Вместо термина «койн (coin)» с таким же успехом можно использовать термин «токен (token)», то есть цифровой маркер, или средство доступа, или механизм отслеживания некой активности» [7].

Таким образом, «токены» в цифровой среде могут выполнять функции сходные с функциями валюты в традиционном ее понимании, т.е. опосредует обмен «товаров» на рынке, используются в качестве средства платежа и т.д.

Однако, «токены» имеют разные функции и могут служить различным целям, среди них можно выделить несколько основных видов «токенов», применение которых необходимо урегулировать гражданским законодательством, - платежные (криптовалюта), кредитные, программные и утилитарные токены.

Наиболее известными широкому кругу лиц являются платежные токены, которые могут быть использованы для оплаты товаров, работ и услуг, совершаемых как в реальной среде, так и в виртуальном пространстве, однако в действующем отечественном законодательстве платежные токены закрепления не получили, а понятие «цифровые деньги» было исключено из проекта закона о внесении изменений в Гражданский кодекс РФ. При этом необходимо отметить, что ст. 1 Федерального закона от 10 декабря 2003 года № 173-Ф3 «О валютном регулировании и валютном контроле», содержит несколько правовых категорий, к которым можно было бы отнести платежные токены, поэтому дискуссионным представляется вопрос о том, являются ли токены «валютой» или «ценными бумагами». В связи с чем целесообразным было бы законодательное закрепление правовой природы токена в отраслевом законодательстве, его статуса как платежного средства на территории Российской Федерации, пределы использования и порядок налогообложения.

Другим видом токенов выступаю кредитные токены, закрепляющие обязательственные отношения между субъектами гражданского права, в том числе право кредитора на возврат денежных средств на условиях, определенных программой. Фактическое применение кредитных токенов на практике означает необходимость изменения норм, регламентирующих в настоящее время форму кредитного договора.

Отличительной чертой программных токенов является отсутствие имущественного характера, поскольку они предоставляют их обладателю право на действия исключительно внутри компьютерной системы. Например, при персонификации контрагента при заключении сделок, особенности правового регулирования которых нашли отражения в изменениях, внесенных в ст. 160, 309, 434 ГК РФ [8].

Российский законодатель, давая определение цифровым правам, сконструировал его наиболее близко по содержанию к утилитарным токенам, которые отражают права их владельца на работы, услуги, вещи (движимые и недвижимые), иные объекты. Так, согласно ст. 141.1. ГК РФ «Цифровыми правами признаются названные в таком качестве в законе обязательственные и иные права, содержание и условия осуществления которых определяются в соответствии с правилами информационной системы, отвечающей установленным законом признакам» [8].

Исходя из вышеизложенного отметим, что цифровые права - это относительно новая категория. Их появлению послужило создание такой технологии как блокчейн, на базе которой были разработаны токены, для использования которых необходимо защитить права субъектов гражданского права посредством законодательного регулирования цифровых прав во всех их проявления, с учетом специфики разновидностей токенов. 


\section{ЛИТЕРАТУРА}

1. Статистика сети «Интернет» 2019 год / [Электронный ресурс]. - Режим доступа: URL: https://www.web-canape.ru/business/vsya-statistika-interneta-na2019-god-v-mire-i-v-rossii/ (дата обращения: 11.09.2020).

2. Письмо Федеральной антимонопольной службы Российский Федерации «0 рекламе алкогольной продукции в Интернете и печатных СМИ» от 03.08.2012 № AK/24981 / [Электронный ресурс]. - Режим доступа:URL: http://www.consultant.ru/document/cons_doc_LAW_134335/ (дата 0бращения: 20.09.2020).

3. Минбалеев А.В., Сафронов Е.Г. Правовая природа блокчейн // Вестник ЮУрГУ. Серия: Право. 2018. №2. С.94-98.

4. Yaga D., Mell P., Roby N., Scarfone K. Blockchain Technology Overview // NIST. 2018 / [Электронный ресурс]. - Режим доступа: URL: https://nvlpubs.nist.gov/ nistpubs/ir/2018/NIST.IR.8202.pdf. (дата обращения: 10.09.2020).

5. Гонгало Б.М., Новоселова Л.А. Есть ли место «цифровым правам» в системе объектов гражданского права // Пермский юридический альманах. 2019. №2. С. 180-184.

6. Голивцова Н.Н, Абдуллаев А.М. Финансирование инновационной организации при помощи первичного размещения монет // Инновационная экономика: перспективы развития и совершенствования. 2018. №2 (28). С. 4-9.

7. Свон М. Блокчейн: Схема новой экономики. М.: «Олимп-Бизнес», 2017. С. 161.

8. Федеральный закон «0 внесении изменений в части первую, вторую и статью 1124 части третьей Гражданского кодекса Российской Федерации» от 18.03.2019 № 34-Ф3 // КонсультантПлюс. URL: http://www.consultant.ru/document/cons_doc_LAW_320398/ (дата 0бращения: 20.09.2020).

с Майборода Татьяна Юрьевна (хxх092020@gmail.com)

Журнал «Современная наука: актуальные проблемы теории и практики»

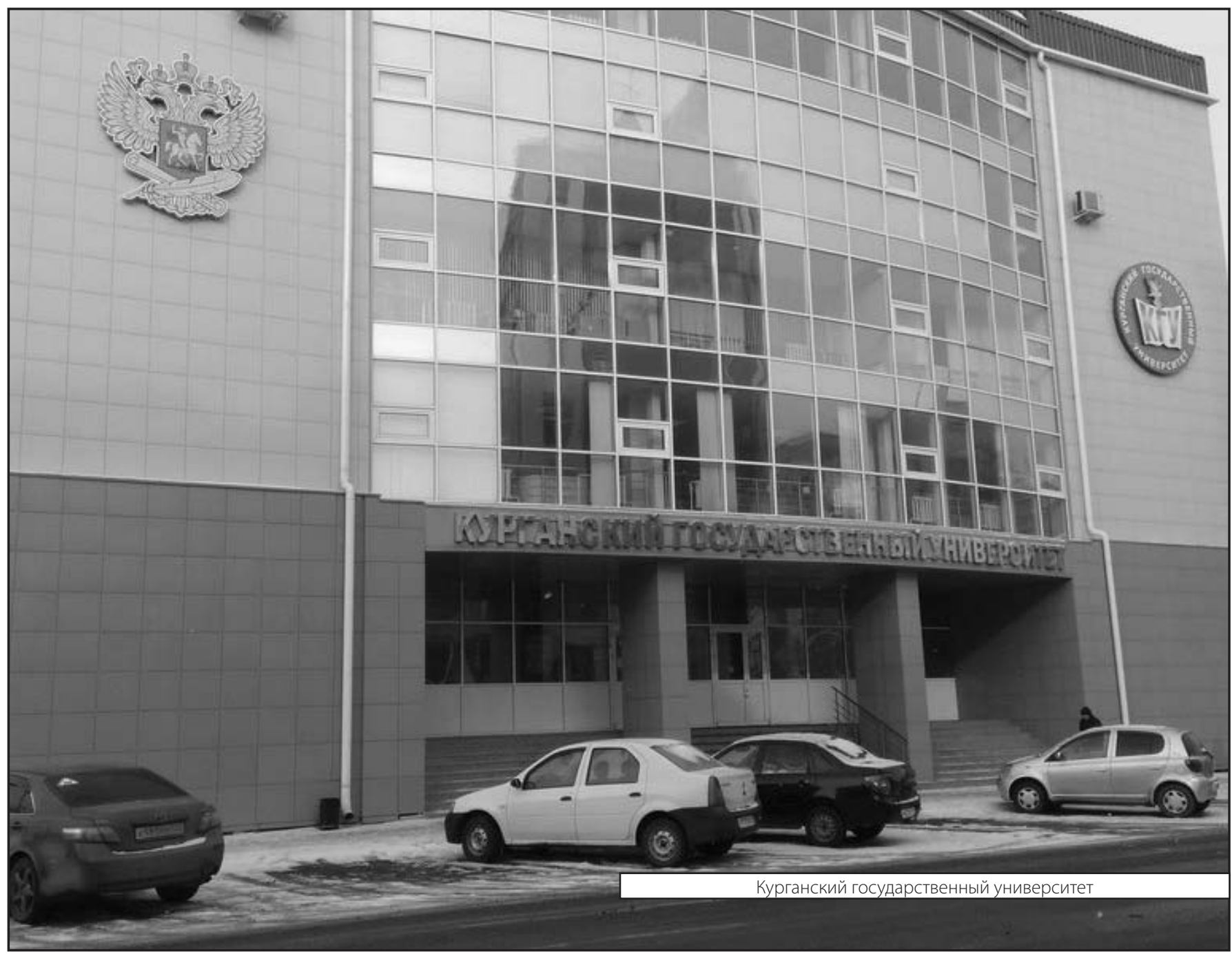

